\title{
Penerapan akupresur pada titik P6 terhadap emesis gravidarum pada ibu hamil trimester 1
}

\author{
Ana Mariza', Lia Ayuningtias ${ }^{2}$
}

1,2 Program Studi Kebidanan Universitas Malahayati Bandar Lampung. Email: mariza.ana22@gmail.com

\author{
Abstract \\ Effect of nei-guan point (P6) acupressure on nausea and vomiting in women with \\ hyperemesis gravidarum
}

\begin{abstract}
Background: Prevalence of emesis gravidarum issued by the explains that more than $80 \%$ of pregnant women in Indonesia experience excessive nausea and vomiting. the incidence of gravidarum emesis cases is 0.8 to 32 cases per 1,000 pregnancies. Therefore, the treatment of labor pain is necessary mother of birth.. While in the year 2017 period January-December as many as 56 cases of hyperemesis gravidarum of 132 visits and 26 pregnant women (46.43\%) received treatment and medical treatment.
\end{abstract}

Purpose: Knowing the effect of giving acupressure point P6 to nausea and vomiting in pregnant women TM I in BPM Wirahayu Panjang Year 2018.

Methods: Quantitative research type, experimental quasi research design with one group pretest - posttest design approach. The number of population and samples is 30 people, purposive sampling technique samples. Data Analysis using t-test.

Results: Showed vomiting before being given intervention Mean 10.53 Min 9 Max 13 and Standard Deviation 1.408 and Standard Error 0.257, after being given acupressure Mean 7.30 Min 5 Max 10 and Standard Deviation 1,317 and Standard Error 0.240 . Statistical test results obtained P-value $=0.000$ means that there is an effect of p6 point acupressure on nausea and vomiting in pregnant women TM I at BPM Wirahayu Panjang in 2018.

Conclusion: Acupressure stimulates the regulatory system and activates endocrine and neurological mechanisms, by stimulating the hypothalamus to removing endorphins which give a sense of relaxation.

Suggestions: are used as input in providing information about nausea and vomiting, understanding, handling and impact if nausea vomiting is allowed, besides providing benefits and information resources for mothers about handling nausea and vomiting using acupressure massage in daily life

\section{Keywords: Nei-guan point (P6); Acupressure; Nausea; Vomiting; Women; Hyperemesis; Gravidarum}

Pendahuluan: Prevalensi emesis gravidarum lebih dari $80 \%$ wanita hamil di Indonesia mengalami mual dan muntah yang berlebihan. Insidensi terjadinya kasus emesis gravidarum sebesar 0,8 sampai 32 kasus per 1.000 kehamilan. Oleh sebab itu penanganan mual muntah pada kehamilan sangat perlu dilakukan terhadap ibu hamil TM 1. Sedangkan pada tahun 2017 periode Januari-Desember sebanyak 56 kasus hyperemesis gravidarum dari 132 kunjungan kehamilan dan 26 orang ibu $(46.43 \%)$ mendapat perawatan dan tindakan medis.

Tujuan: Diketahui pengaruh pemberian akupresure titik P6 terhadap mual dan muntah pada ibu hamil TM I di BPM Wirahayu Panjang Tahun 2018.

Metode: Jenis penelitian kuantitatif, rancangan penelitian quasi eksperimental dengan pendekatan one group pretest - posttest design. Jumlah populasi 120 orang ibu hamil dan sampel sebanyak 30 orang, teknik sampel purposive sampling. Analisa Data menggunakan uji t-test.

Hasil: Menunjukan muntah sebelum diberi intervensi Mean 10.53 Min 9 Max 13 danStandar Deviasi 1.408 dan Standar Eror 0.257, sesudah diberi akupresur Mean 7.30 Min 5 Max 10 dan Standar Deviasi 1.317 dan Standar Eror 0.240 . Hasil uji statistik didapatkan nilai $P$-value $=0.000$ artinya terdapat Pengaruh pemberian akupresure titik p6 terhadap mual dan muntah pada ibu hamil TM I di BPM Wirahayu Panjang Tahun 2018.

Simpulan: Akupresur menstimulasi system regulasi serta mengaktifkan mekanisme endokrin dan neurologi, dengan cara merangsang kerja hipotalamus untuk mengeluarkan zat endorphin yang memberikan rasa rileks.

Saran: Sebagai masukan dalam memberikan informasi tentang mual dan muntah, pengertian, penanganan dan 
Penerapan akupresur pada titik P6 terhadap emesis gravidarum pada ibu hamil trimester 1

dampak jika mual muntah dibiarkan, selain itu memberikan manfaat dan sumber informasi bagi ibu tentang penanganan mual muntah menggunakan pijat akupresur dalam kehidupan sehari-hari

\section{Kata Kunci: Penerapan akupresur; Titik P6; Emesis gravidarum; Ibu hamil trimester 1}

\section{PENDAHULUAN}

Emesis gravidarum adalah gejala yang wajar atau sering terdapat pada kehamilan trimester pertama. Mual biasanya terjadi pada pagi hari, tetapi ada yang timbul setiap saat dan malam hari. Gejala-gajala ini biasanya terjadi 6 minggu setelah hari pertama haid terahir dan berlangsung kurang lebih 10 minggu (Wiknjosastro, 2010; Puriati, \& Misbah, 2014).

WHO sebagai badan PBB yang menangani masalah bidang kesehatan, mengatakan bahwa Hiperemesis Gravidarum terjadi diseluruh dunia, diantaranya negara- negara di benua Amerika dengan angka kejadian yang beragam. Sementara itu, kejadian Hiperemesis Gravidarum juga banyak terjadi terjadi di Asia contohnya di Pakistan, Turki dan Malaysia. Sementara itu, angka kejadian Hiperemesis Gravidarum di Indonesia adalah mulai dari $1 \%$ sampai $3 \%$ dari seluruh kehamilan (Aril, 2012).

Kematian dan kesakitan pada ibu hamil dan bersalin serta bayi baru lahir sejak lama telah menjadi masalah, khususnya di negara- negara berkembang. Hal-hal yang berdasarkan penyebab kematian ibu hamil, diantaranya disebabkan oleh hyperemesis gravidarum sekitar $25-50 \%$ dan hal yang berkaitan dengan kehamilan. Kematian saat melahirkan menjadi penyebab utama mortalitas perempuan pada masa puncak produktifitasnya. World Health Organization (WHO) memperkirakan setiap tahun terjadi 210 juta kehamilan diseluruh dunia. Dari jumlah ini 20 juta perempuan mengalami kesakitan sebagai akibat kehamilan. Sekitar 8 juta mengalami komplikasi yang mengancam jiwa, dan lebih dari 500.000 meninggal pada tahun 1995 . Sebanyak 240.000 dari jumlah ini hampir $50 \%$ terjadi di negara-negara Asia Selatan dan Tenggara, termasuk Indonesia. (Kementrian Kesehatan Republik Indonesia, 2014). Prevalensi Hiperemesis Gravidarum lebih dari $80 \%$ wanita hamil di Indonesia mengalami mual dan muntah yang berlebihan. insidensi terjadinya kasus Hiperemesis Gravidarum sebesar 0,8 sampai $3,2 \%$ dari seluruh kehamilan atau sekitar 8 sampai 32 kasus per 1.000 kehamilan di dunia. Angka Kematian Ibu (AKI) berdasarkan laporan dari SDKI tahun 2012 sebesar 359 per 100.000 kelahiran hidup (target 102 per 100.000 kelahiran hidup). Bila dilihat berdasarkan kasus kematian yang ada di Provinsi Lampung tahun 2015 penyebab kasus kematian ibu di Provinsi lampung tahun 2015 disebabkan oleh perdarahan sebanyak 46 kasus, hipertensi sebanyak 35 kasus, infeks sebanyak 7 kasus, ganguan sistem peredaran darah sebanyak 10 kasus, gangguan metabolik sebanyak 3 kasus dan lain-lain sebanyak 48 kasus (Badan Pusat Statistik dan Badan Kependudukan dan Keluarga Berencana Nasional, 2013 ; Oktavia, 2016)

Angka kejadian hyperemesis gravidarum di BPM Wirahayu pada tahun 2016 periode JanuariDesember sebanyak 42 ibu hamil mengalami hyperemesis gravidarum dari 129 kunjungan kehamilan dan 20 ibu (47.62\%) diantaranya mendapat perawatan dan tindakan medis. Sedangkan pada tahun 2017 periode JanuariDesember sebanyak 56 kasus hyperemesis gravidarum dari 132 kunjungan kehamilan dan 26 orang ibu (46.43\%) mendapat perawatan dan tindakan medis.

Penatalaksanaan mual dan muntah pada kehamilan tergantung pada beratnya gejala. Pengobatan yang dilakukan mulai dari yang paling ringan dengan perubahan diet sampai pendekatan dengan pengobatan antimietik, rawat inap, atau pemberian nutrisi parenteral. Pengobatan terdiri atas terapi secara farmakologi dan non farmakologi. Terapi farmakologi dilakukan dengan pemberian antimietik, antihistamin, dan kortikosteroid. Terapi non farmakologi dilakukan dengan cara pengaturan diet, dukungan emosional, akupresur dan jahe (Runiari, 2010).

Akupresur (titik perikardium 6) yaitu sebuah tindakan untuk mengurangi atau menurunkan rasa mual dan muntah pada kehamilan yang dilakukan dengan cara penekanan pada titik tubuh tertentu (titik perikardium 6 atau tiga jari di bawah pergelangan tangan). Akupresur adalah cara pijat berdasarkan ilmu akupuntur atau bisa juga disebut akupuntur tanpa jarum. Terapi akupresur menjadi salah satu terapi nonfarmakologis berupa terapi pijat pada titik meridian tertentu yang berhubungan dengan organ dalam tubuh untuk mengatasi mual muntah. Terapi ini tidak memasukkan obatobatan ataupun prosedur invasif melainkan dengan

Ana Mariza', Lia Ayuningtias ${ }^{2}$ Program Studi Kebidanan Universitas Malahayati Bandar lampung.

Email: mariza.ana22@gmail.com 
Penerapan akupresur pada titik P6 terhadap emesis gravidarum pada ibu hamil trimester 1

mengaktifkan sel-sel yang ada dalam tubuh, sehingga terapi ini tidak memberikan efek samping seperti obat dan tidak memerlukan biaya mahal. Pada prinsip terapi akupresur sama dengan memijat sehingga tidak memerlukan keterampilan khusus beda halnya dengan akupuntur yang memerlukan pelatihan. Terapi akupresur untuk mual muntah dilakukan dengan menekan secara manual pada Pericardium 6/ Perikardium 6 (Fitriana, 2017; Wong, 2011 ; Fengge, 2012).

BPM Wirahayu merupakan salah satu BPM yang berada diwilayah kerja Puskes dan dengan jumlah perata kunjungan ANC pada ibu hamil sebanyak 18-25 ibu setiap bulannya. Berdasarkan hasil presurvey di BPM Wirahayu Panjang terhadap 10 orang ibu hamil trimester I didapat hasil 6 orang (60\%) mengalami emesis gravidarum, dan 4 orang $(40 \%)$ tidak mengalami hyperemesis gravidarum. Berdasarkan keterangan yang didapat ibu yang mengalami mual dan muntah berlebihan, biasanya akan mengkonsumsi gula yang dicampur kopi kemudian cukup dimakan seperti saat makan permen, sedangkan sisanya biasanya mengkonsumsi permen jahe. Di BPM Wirahayu terapi akupresur belum pernah dilakukan untuk mengurangi kejadian mual dan muntah yang berlebih, maka peneliti tertarik untuk melakukan penelitian dengan tema akupresur.

\section{METODE PENELITIAN}

Penelitian kuantitatif, Pra Eksperimental dengan pendekatan one group pretest - posttest design. Populasi dalam penelitian ini adalah seluruh Ibu hamil TM 1 dengan emesis gravidarum sebanyak 30 orang ibu hamil dan tidak ada kelompok kontrol., Sampel dalam penelitian ini adalah Ibu hamil TM I di BPM Wirahayu Panjang. Teknik sampling purposive sampling, serta analisa data secara univariat dan bivariate dengan Uji $\mathrm{T}$ Test. Dengan kriteria insklusi : Usia gestasional 1016 minggu, usia ibu hamil antara 20-40 tahun dengan keluhan mual dan muntah sedang (emesis) dengan nilai INVR 9-16 nilai sedang.

Istrumen memakai Kuisioner Indeks Rhodes dan lembar observasi, adapun tahap tindakannya sesuai standar operasional prosedur (SOP) tindakan medis dan selanjutnya melakukan pemijatan yang dilakukan pada bagian 3 jari diatas pergelangan tangan dengan cara melingkar, dilakukan selama 7 menit setiap pagi hari. Teknik ini dilakukan selama 4 hari secara sendiri-sendiri oleh pasien. Evaluasi dilakukan pada hari ke 5 di pagi hari dengan menggunakan kuisioner indeks Rhode

HASIL

Tabel 1. Rata-Rata Mual Dan Muntah Ibu Hamil TM I Sebelum Penerapan Akupresur Pada Titik P6

\begin{tabular}{lcccccc}
\hline Variabel & N & Mean & Min- Max & Std. Dev & Std, Eror & Cl-95\% \\
\hline Mual Dan Muntah Sebelum Intervensi & 30 & 10.53 & $9-13$ & 1.408 & 0.257 & $10.01-11.06$
\end{tabular}

Dari tabel 1 diatas dapat diketahui bahwa rata-rata mual dan muntah ibu hamil TM I sebelum diberi terapi akupresur dengan nilai Mean 10.53 nilai Min 9 nilai Max 13 dan nilai Standar Deviasi 1.408 dan nilai Standar Eror 0.257 .

\section{Tabel 2. Rata-Rata Mual Dan Muntah Ibu Hamil TM I Sesudah Penerapan Akupresur Pada Titik P6}

\begin{tabular}{lcccccc}
\hline Variabel & N & Mean & Min- Max & Std. Dev & Std, Eror & Cl-95\% \\
& & & & & & \\
\hline Mual Dan Muntah Sesudah Intervensi & 30 & 7.30 & $5-10$ & 1.317 & 0.240 & $6.81-7.79$ \\
& & & & & & \\
\hline
\end{tabular}

Dari tabel 2 diatas dapat diketahui bahwa rata-rata emesis gravidarum ibu hamil TM I sesudah diberi terapi akupresur dengan nilai Mean 7.30 nilai Min 5 nilai Max 10 dan nilai Standar Deviasi 1.317 dan nilai Standar

Ana Mariza', Lia Ayuningtias ${ }^{2}$ Program Studi Kebidanan Universitas Malahayati Bandar lampung.

Email: mariza.ana22@gmail.com 
Eror 0.240

Tabel 3. Pengaruh Penerapan Akupresur Pada Titik P6 Terhadap Emesis Gravidarum

\begin{tabular}{lcccccc}
\hline Variabel & $\mathbf{N}$ & Mean & Std. Dev & SE & $p$-value & Cl-95\% \\
\hline pretest & 30 & 10.53 & 1.408 & 0.257 & \multirow{2}{*}{0.000} & $2.656-$ \\
Posttest & 30 & 7.30 & 1.317 & 0.240 & & 3.811
\end{tabular}

Dari tabel 3 terlihat bahwa rata-rata emesis gravidarum 30 responden dengan Mean 10.53 Min 9 Max 13 dan Standar Deviasi 1.408 dan Standar Eror 0.257 pada pengukuran ke dua didapat 30 responden dengan emesis gravidarum setelah diberi pijat akupresur dengan Mean 7.30 Min 5 Max 10 dan Standar Deviasi 1.317 dan Standar Eror 0.240. Hasil uji statistik didapatkan nilai $p$ value $=0.000$ yang artinya terdapat pengaruh pemberian akupresure titik $p 6$ terhadap emesis gravidarum.

\section{PEMBAHASAN}

Rata-rata emesis gravidarum ibu hamil TM I sebelum diberi terapi akupresur di BPM Wirahayu Tahun 2018 dengan Mean 10.53 Min 9 Max 13 dan Standar Deviasi 1.408 dan Standar Eror 0.257 . Sejalan dengan teori yang dikemukakan bahwa mual (nausea) dan muntah (emesis) adalah gejala yang wajar dan sering kedapapatan pada kehamilan trimester I. Mual biasanya terjadi pada pagi hari, tetapi dapat pula timbul setiap saat dan malam hari gejala- gejala ini kurang lebih 6 minggu setelah hari pertama haid terakhir dan berlangsung selama kurang lebih 10 minggu. Emesis Gravidarum merupakan keluhan umum yang disampaikan pada kehamilan muda. Terjadinya kehamilan menimbulkan perubahan hormonal pada wanita karena terdapat peningkatan hormon estrogen, progesteron, dan dikeluarkannya human chorionic gonadothropine plasenta. Hormon inilah yang menyebabkan emesis gravidarum (Oxorn, \& Forte, 2010; Manuaba, 2009).

Sejalan dengan penelitian yang dilakukan menjelaskan bahwa akupresur pada titik PC 6 dapat menurunkan mual untuk kehamilan, sedangkan pada penelitian pada titik ST 36 dan SP 3 dapat mengatasi mual muntah pada pasien dispepsia, dan penelitian pada titik ST 36 dan PC 6 dapat menurunkan mual muntah lambat akibat kemoterapi pada anak usia sekolah yang mengalami kanker. Titik ST 36 dan PC 6 merupakan bagian dari titik akupresur, yang belum banyak dijelaskan oleh para peneliti terhadap mual dan muntah atau morning sickness bagi ibu hamil. Sehingga, peneliti tertarik untuk meneliti pengaruh akupresur terhadap morning sickness ibu hamil trimester pertama di Kecamatan Magelang Utara (Mayasari, \& Savitri, 2013).

Mual dan muntah atau yang disebut dengan emesis gravidarum merupakan keluhan umum pada kehamilan muda. Terjadinya kehamilan menimbulkan perubahan hormonal pada wanita karena terdapat peningkatan hormone estrogen, progesterone, dan pengeluaran HCG plasenta. Mual dan muntah juga dapat disebabkan oleh perubahan hormone dan keadaan tubuh untuk menyiapkan posisi atau rumah baru bagi janin.

Pada penelitian ini emesis gravidarum paling sedikit nilai minimal 6 dan nilai maksimal 13 , frekuensi mual dan muntah tersebut dapat disebabkan oleh respon tubuh terhadap benda, bau, atau makanan yang dikonsumsi, selain itu penanganan dan pengelolaan mual muntah sangat diperlukan bagi ibu hamil, seperti memberikan makanan yang hangat, cemilan atau cracker, serta penatalaksanaan non farmakologi (hobat herbal) dengan harapan mual dan muntah dapat teratasi, dan tidak mengganggu asupan nutrisi ibu.

Patofisiologi Emesis gravidarum dapat disebabkan karena peningkatan Hormone Chorionic Gonodhotropin (HCG) dapat menjadi faktor mual dan muntah (Shanti, Barokah, \& Rahayu, 2018). Peningkatan kadar hormon progesteron menyebabkan otot polos pada sistem gastrointestinal mengalami relaksasi sehingga motilitas menurun dan lambung menjadi kosong.

Ana Mariza', Lia Ayuningtias² Program Studi Kebidanan Universitas Malahayati Bandar lampung.

Email: mariza.ana22@gmail.com 
Penerapan akupresur pada titik P6 terhadap emesis gravidarum pada ibu hamil trimester 1

Hiperemesis gravidarum yang merupakan komplikasi ibu hamil muda bila terjadi terus menerus dapat mengakibatkan dehidrasi, ketidakseimbangan elektrolit, serta dapat mengakibatkan cadangan karbohidrat dan lemak habis terpakai untuk keperluan energi (Gunawan, Manengkei, \& Ocviyanti, 2011).

Penatalaksanaan mual dan muntah yang paling sering dilakukan adalah dengan memberikan minuman hangat dan menyegarkan, akan tetapi tidak sedikit jug aibu yang menolak, salah satu pendekatan non farmakologi yang bisa diberikan adalah dengan akupresur (Arviana, 2017). Akupresur adalah metode pengobatan dari tiongkok kuno dengan menstimulasi titik khusus dibadan dengan menggunakan jarum bagi akupuntur dan menggunakan ujung jari pada akupresur karena bersifat penekanan pada tiik tubuh tertentu. Sesi akupresur dan akupuntur sebaiknya dilakukan 2-3 kali dalam seminggu, akupresur dan akupuntur menstimulasi system regulasi serta mengaktifkan mekanisme endokrin dan neurologi, yang merupakan mekanismse fisiologi dalammempertahankan keseimbangan, penekanan secara manual pada P6 atau pericardium 6 pada daerah pergelangan tangan yaitu 3 jari dari derah distal pergelangan tangan atau dua tendon selama 2 menit (Gunawan, Manengkei, \& Ocviyanti, 2011).

Penelitian yang pernah dilakukan di Lombok dimana pemberian aromaterapi jeruk juga lebih efektif dalam menurunkan mual muntah pada Ibu hamil trimester I yang ditunjukkan dengan nilai $p$ $(0,000<0,05)$. Pembuktian akupresure perikardium dan pemberian aromaterapi jeruk mempunyai pengaruh terhadap penurunan mual muntah pada ibu hamil Trimester I. Namun aroma terapi jeruk lebih efektif menurunkan mual muntah pada ibu hamil. Sehingga diharapkan kedua teknik dalam penelitian ini bisa menjadi bagian teknik yang bisa dimanfaatkan untuk menurunkan mual muntah pada Ibu hamil Trimester I (Fitriani, 2017).

Menstimulasi system regulasi serta mengaktifkan mekanisme endokrin dan neurologi, yang merupakan mekanisme fisiologi dalam muntah pada kategori ringan dan sedang (Sulistiarini, Widyawati, \& Rahayu, 2018). Dalam literature review ini Beberapa literatur menjelaskan akupresur lebih efektif mengatasi mual dan muntah pada ibu hamil. Proses dengan teknik akupresur menitik beratkan pada titik-titik saraf tubuh. Akupresur dipercaya dapat meningkatkan atau menghidupkan organ-organ yang sakit, sehingga dapat memperlancar peredaran darah yang terganggu.

Hasil uji statistik didapatkan nilai $p$-value $=0.000$ yang artinya terdapat Pengaruh pemberian akupresure titik p6 terhadap emesis gravidarum, sejalan dengan teori yang dikemukakan Bahwa emesis gravidarum adalah keadaan mual muntah yang lebih dari 10 kali dalam 24 jam atau setiap saat wanita hamil sampai mengganggu pekerjaan sehari- hari karena pada umumnya menjadi buruk dan dapat terjadi dehidrasi. Emesis gravidarum adalah mual muntah berlebihan sehingga pekerjaan sehari-hari akan terganggu dan keadaan umum menjadi buruk. Mual muntah merupakan gangguan yang paling sering dijumpai pada kehamilan trimester I. Kurang lebih pada 6 minggu setelah haid berakhir selama 10 minggu. Sekitar $60=80 \%$ primigravida dan $40-60 \%$ multigravida mengalami mual muntah. Namun gejala ini menjadi berat hanya pada 1 dari 1000 kehamilan (Rukiyah, Yulianti, \& Sulitiawati, 2014).

Sejalan dengan penelitian yang dilakukan dengan judul Pengaruh Perawat Menggunakan untuk P6 Akupresur pada Mual, Muntah dan Retching pada Wanita dengan Hiperemesis Gravidaru ini menunjukkan bahwa tidak ada perbedaan yang signifikan secara statistik ditemukan pada karakteristik awal mual, muntah dan skor muntah kering antara P6 acupressure dan kelompok terapi konvensional, sementara ada penurunan yang signifikan dalam rata-rata skor mual, muntah dan muntah-muntah dan skor total dari garis dasar ke 4 hari. Perbedaan antara peningkatan garis dasar dalam kelompok konvensional secara signifikan lebih baik dari grup akupresur di hari yang berbeda. Tingkat peningkatan dibandingkan dengan akupresur P6 ke konvensional adalah 71,9\% hingga $100 \%$ masing-masing.

Akupresur dan akupuntur menstimulasi system regulasi serta mengaktifkan mekanisme endokrin dan neurologi, yang merupakan mekanisme fisiologi dalam muntah pada kategori ringan dan sedang. Dalam literature review ini Beberapa literatur menjelaskan akupresur lebih efektif mengatasi mual dan muntah pada ibu hamil. Proses dengan teknik akupresur menitik beratkan pada titik-titik saraf tubuh. Terapi akupressur, dimana terapi ini dilakukan dengan cara menekan secara manual pada P6 pada daerah pergelangan

Ana Mariza', Lia Ayuningtias ${ }^{2}$ Program Studi Kebidanan Universitas Malahayati Bandar lampung.

Email: mariza.ana22@gmail.com 
Penerapan akupresur pada titik P6 terhadap emesis gravidarum pada ibu hamil trimester 1

tangan yaitu 3 jari dari pergelangan tangan. Terapi ini menstimulasi sistem regulasi serta mengaktifkan mekanisme endokrin dan neurologi, yang merupakan mekanisme fisiologi dalam mempertahankan keseimbangan (Widyastuti, Rumiyati, \& Widyastutik, 2019; Runiari, 2010).

Menurut pendapat peneliti pencegahan terhadap emesis gravidarum dengan cara menganjurkan makan dengan jumlah kecil tetapi lebih sering, anjurkan minum teh hangat dan biskuit, roti kering, selain itu ibu juga diharapkan untuk tidak mengkonsumsi susu secara berlebih ataupun makanan yang mengandung lemak, karena akan meningkatkan rangasangan muntah. Selain itu peanganan dengan memberikan pijatan akupresur pada titik $\mathrm{Pc} 6$, dirasa sangat efektif, ibu hanya perlu menekan bagian 3 jari dibawah pergelangan tangan, dengan cara ibu dianjurkan untuk duduk, atau berbaring dengan posisi senyaman mungkin, ibu dapat mengulang kembali jika ibu merasa nyaman dan rileks.

Pada penelitian ini terdapat 2 ibu yang tidak mengalami penurunan mual muntah, yaitu berada pada skala 9, hal ini dapat disebabkan oleh usia kandungan ibu yang masih muda 10 minggu sehingga ibu belum dapat mentoleransi perubahan system tubuh dan hormone-hormon yang berada dalam tubuh. Pada table 2 diatas dapat dilihat jika nilai skala indek rodek mengalami penurunan yang bervariasi, yaitu antara 5-7 skala dari sebelum ke sesudah intervensi, namun ada 2 responden yang tidak mengalami penurunan skala indek rodek, yaitu pada skala 9 pretes dan skala 9 postes.

Hasil ini dapat dipengaruhi oleh usia ibu yang tergolong usia muda 20 tahun dan 23 tahun, yang artinya ibu belum memiliki banyak pengalaman pada masa, sesuai dengan status paritas ibu yaitu G1P0A0 ibu belum pernah bersalin sebelumnya, dan merupakan kehamilan pertama, pada usia 10 minggu, dimana menurut pendapat yang dikemukakan oleh Wiknjosastro (2009) mual (nausea) dan muntah (emesis) adalah gejala yang wajar dan sering kedapapatan pada kehamilan trimester I. Mual biasanya terjadi pada pagi hari, tetapi dapat pula timbul setiap saat dan malam hari gejala-gejala ini kurang lebih 6 minggu setelah hari pertama haid terakhir dan berlangsung selama kurang lebih 10 minggu.

Emesis Gravidarum merupakan keluhan umum yang disampaikan pada kehamilan muda. Terjadinya kehamilan menimbulkan perubahan hormonal pada wanita karena terdapat peningkatan hormon estrogen, progesteron, dan dikeluarkannya human chorionic gonadothropine plasenta. Hormon inilah yang menyebabkan emesis gravidarum. Selain itu berat badan ibu dipengaruhi oleh keadaan emesis gravidarum, ibu yang kehilangan nutrisi secara berlebihan, akan mengalami gangguan mal nutrisi yang adekuat, dimana jumlah asupan nutrisi tidak sebanding dengan yang dikeluarkan, berat badan ibu yang berkurang akan berdampak pada indeks masa tubuh ibu, yang diukur dengan tinggi badan dan berat badan.

\section{SIMPULAN}

Berdasarkan kesimpulan sebagai berikut: ratarata emesis gravidarum ibu hamil TM I sebelum diberi terapi akupresur didapatkan nilai Mean 10.53 nilai Min 9 nilai Max 13 dan nilai Standar Deviasi 1.408 dan nilai Standar Eror 0.257, dan sesudah diberi terapi akupresur didapatkan nilai Mean 7.30 nilai Min 5 nilai Max 10 Standar Deviasi 1.317 dan nilai Standar Eror 0.240. Hasil uji statistik didapatkan nilai $p$-value $=0.000$ yang artinya terdapat Pengaruh pemberian akupresure titik p6 terhadap emesis gravidarum.

\section{SARAN}

Bagi ibu hamil dapat menggunakan pijat akupresur pada titik P6 yang terletak 3 jari di bawah pergelangan tangan, selama 7 menit, dan dapat dilakukan dimana saja saat ibu hamil merasa mual. Hasil penelitian ini dapat dijadikan sumber informasi bagi institusi kesehatan tentang penanganan emesis gravidarum dengan menggunakan pijat akupresur pada titik P6 yang berada pada 3 jari dibawah pergelangan tangan, selain praktis, pijat akupresur dapat dilakukan di manapun ibu berada, saat ibu beraktivitas, ataupun ibu saat sedang beristirahat. Hasil penelitian ini juga dapat dijadikan bahan referensi dalam melakukan penelitian selanjutnya, yang berhubungan dengan terapi farmakologi pada ibu yang mengalami emesis gravidarum saat hamil.

\section{DAFTAR PUSTAKA}

Aril, C. (2012). Hubungan Antara Karakteristik Ibu Hamil Dengan Kejadian Hiperemesisgravidarum Di RSUD Ujung Berung Pada Periode 2010-2011. Retrieved Februari, 25, 2017. 
Penerapan akupresur pada titik P6 terhadap emesis gravidarum pada ibu hamil trimester 1

Arviana, A. (2017). Hubungan Morbiditas Pre Menstrual Syndrome (Pms) Dengan Tingkat Kecemasan Dan Kualitas Tidur Pada Remaja Putri (Studi Di SMP Muhammadiyah 4 Malang) (Doctoral Dissertation, University Of Muhammadiyah Malang).

Badan Pusat Statistik dan Badan Kependudukan dan Keluarga Berencana Nasional. (2013). Survei demografi dan kesehatan Indonesia 2012. Jakarta: BPS.

Fengge, A. (2012). Terapi Akupresur Manfaat dan Teknik Pengobatan. Yogyakarta: Crop Circle Corp.

Fitriana, D. (2017). Perbandingan efektifitas akupresure perikardium dengan aromaterapi terhadap penurunan mual muntah pada lbu hamil di Pulau Lombok. PrimA: Jurnal IImiah IImu Kesehatan, 2(1).

Gunawan, K., Manengkei, P. S. K., \& Ocviyanti, D. (2011). Diagnosis dan Tata Laksana Hiperemesisi Gravidarum. J Indon Med Assoc, Volum, 61.

Kementrian Kesehatan Republik Indonesia. (2014). Laporan Nasional Riset Kesehatan Dasar (Riskesdas) tahun 2013. Jakarta: Kemenkes RI.

Manuaba, I. A. C. (2009). Buku Ajar Patologi Obstetri. EGC.

Mayasari, D. A., \& Savitri, W. (2013). Terapi Relaksasi Akupresur Untuk Mengatasi Keluhan Mual Dan Muntah Pada Ibu Hamil. Media IImu Kesehatan, 2(2), 96-100.

Oktavia, L. (2016). Kejadian Hiperemisis Gravidarum Ditinjau dari Jarak Kehamilan dan Paritas. Jurnal Aisyah: Jurnal IImu Kesehatan, 1(2), 41-46.

Oxorn, H., \& Forte, W. R. (2010). IImu kebidanan: patologi dan fisiologi persalinan. Penerbit Andi.
Rukiyah, A. Y., Yulianti, L., \& Sulitiawati, L. (2009). Asuhan Kebidanan I (Kehamilan). Jakarta: trans info media.

Runiari, N. (2010). Asuhan keperawatan pada klien dengan hiperemesis gravidarum: penerapan konsep dan teori keperawatan. Jakarta: Salemba Medika.

Shanti, E. F. A., Barokah, L., \& Rahayu, B. (2018). Efektivitas Pemberian Pisang Ambon Dan Vitamin B Untuk Menurunkan Hiperemesis Gravidarum Di Bpm Endah Bekti. Media IImu Kesehatan, 7(1), 17-21.

Sulistiarini, U., Widyawati, M. N., \& Rahayu, D. L. (2018). Studi Literatur: Acupressure Pericardium Dan Aromatherapy Citrus Untuk Mengurangi Mual Muntah Ibu Hamil. Jurnal Kebidanan, 8(2), 146-156.Studi Literatur: Acupressure Pericardium Dan Aromatherapy Citrus Untuk Mengurangi Mual Muntah lbu Hamil. Jurnal Kebidanan, 8(2), 146-156.

Titisari, I., Suryaningrum, K. C., \& Mediawati, M. (2019). Hubungan Antara Status Gravida Dan Usia lbu Dengan Kejadian Emesis Gravidarum Bulan Januari-Agustus 2017 Di Bpm Veronika Dan Bpm Endang Sutikno Kota Kediri. Jurnal IImu Kesehatan, 7(2), 342-348.

Widyastuti, D. E., Rumiyati, E., \& Widyastutik, D. (2019). Terapi Komplementer Akupresur Untuk Mengatasi Emesis Gravidarum Pada Ibu Hamil Trimester I Tahun 2018. Jurnal Kebidanan Indonesia: Journal of Indonesia Midwifery, 10(1), 96-104.

Wiknjosastro, I. K. (2007). Penerbit Yayasan Bina Pustaka Sarwono Prawirohardjo.

Wong, M. F. (2011). Panduan Lengkap Pijat. Penebar PLUS+. 